Available online at http://journal.stkip-andi-matappa.ac.id/index.php/histogram/index

Histogram: Jurnal Pendidikan Matematika 4(2)., 2020, 601 - 615

\title{
PENERAPAN MODEL CPS BERBASIS LKS SOAL TIMSS UNTUK MENGUKUR KEMAMPUAN PEMECAHAN MASALAH
}

\author{
Rahmat Kamaruddin 1* Firdha Razak ${ }^{2}$, Ahmad Budi Sutrisno ${ }^{3}$ \\ 1,2,3 STKIP Andi Matappa \\ * Corresponding Author. Email: rahmat@stkip-andi-matappa.ac.id \\ Received: 10 Agustus 2020; Revised: 15 September 2020 ; Accepted: 30 September 2020
}

\begin{abstract}
ABSTRAK
Penelitian ini bertujuan untuk menerapkan model pembelajaran Creative Problem Solving (CPS) dengan menggunakan LKS soal TIMSS pada konten aljabar untuk mengukur kemampuan pemecahan. Populasi dalam penelitian ini seluruh siswa VII SMP Negeri 1 Pangkajene berjumlah 180 siswa dan sampel sebanyak 32 siswa yang diambil dengan teknik simple random. Instrumen dalam penelitian ini adalah 1) LKS soal TIMSS; 2) Tes kemampuan pemecahan masalah; 3) Pedoman wawancara. Data akan dianalisis deskriptif kuantitatif serta analisis inferensial. Hasil penelitian diperoleh: 1) kemampuan pemecahan masalah siswa (pretest) sesuai aspek yang dinilai dalam TIMSS dianalisis secara deskriptif berada pada interpretasi sedang yakni sebesar 10 siswa atau 33\% dari 32 siswa sedangkan kemampuan pemecahan masalah siswa(posttest) berada pada interpretasi tinggi yakni sebesar 17 siswa atau 54\% dari 32 siswa. Hasil uji gain ternormalisasi yaitu 0,52 yang berarti peningkatan hasil belajar siswa yang diajar dengan model pembelajaran CPS berada pada kategori sedang. 2) Presentase rata-rata siswa yang memberi respon positif terhadap penerapan model CPS sebesar $81 \%$. 3) Secara inferensial, penerapan model pembelajaran CPS tuntas secara klasikal serta memiliki daya dongkrak peningkatan gain sebesar 0,3 atau terdapat peningkatan rata-rata nilai gain ternormalisasi secara signifikan sehingga model ini baik digunakan dalam pembelajaran matematika di SMP Negeri 1 Pangkajene.
\end{abstract}

Kata Kunci: Kemampuan Pemecahan Masalah, CPS, LKS, TIMSS

\section{ABSTRACT}

This study aims to apply the Creative Problem Solving (CPS) learning model using TIMSS question worksheets on algebraic content to measure solving abilities. The population in this study were all VII students of SMP Negeri 1 Pangkajene totaling 180 students and a sample of 32 students who were taken using simple random technique. The instruments in this study were 1) worksheets on TIMSS questions; 2) Test problem solving skills; 3) Interview guidelines. The data will be analyzed descriptive quantitative and inferential analysis. The results obtained: 1) students 'problem solving abilities (pretest) according to the aspects assessed in the TIMSS were analyzed descriptively in moderate interpretation, which was 10 students or $33 \%$ of 32 students, while the students' problem solving abilities (posttest) were at high interpretation which was equal to 17 students or $54 \%$ of 32 students. The normalized gain test result is 0.52 , which means that the increase in student learning outcomes taught by the CPS learning model is in the medium category. 2) The average percentage of students who responded positively to the application of the CPS model was $81 \%$. 3) Inferential, the application of the CPS learning model is complete classically and has a boost to increase the gain of 0.3 or there is an increase in the average normalized gain value significantly so that this model is good for use in mathematics learning at SMP Negeri 1 Pangkajene.

Keywords: Problem Solving Skills, CPS, LKS, TIMSS

How to Cite: Kamaruddin, R., Razak, F.\& Sutrisno, A, B. (2020). Penerapan Model CPS Berbasis LKS Soal TIMSS Untuk Mengukur Kemampuan Pemecahan Masalah. Histogram: Jurnal Pendidikan Matematika, 4(2), $600 \quad-\quad 615, \quad$ doi: http://dx.doi.org/10.31100/histogram.v4i2.828

Permalink/DOI: http://dx.doi.org/10.31100/histogram.v4i2.828 


\section{Histogram: Jurnal Pendidikan Matematika, 4 (2), 2020 - 602 Rahmat Kamaruddin ${ }^{*}$, Firdha Razak ${ }^{2}$, Ahmad Budi Sutrisno ${ }^{3}$}

\section{PENDAHULUAN}

Matematika sekolah adalah matematika yang diajarkan di jenjang persekolahan yaitu Sekolah Dasar, Sekolah Menengah Pertama dan Sekolah Menengah Atas. Matematika sekolah memiliki ciri-ciri yang dimiliki matematika, yaitu memiliki objek kajian yang abstrak serta berpola pikir deduktif konsisten. Salah satu hal penting dalam belajar matematika sekolah adalah tentang pemecahan masalah. Menurut Polya (dalam (Uno, 2012)) dalam suatu pemecahan masalah terdapat 4 (empat) yang harus dilakukan, yaitu 1) memahami masalah, 2) membuat rencana pemecahan masalah, 3) melaksanakan rencana, 4) memeriksa kembali jawaban.

Kemampuan pemecahan masalah matematika dari waktu ke waktu belum meningkat. Hal ini dapat dilihat hasil rerata nilai nasional UNBK jenjang SMP tahun ini mencapai 51,84 dengan nilai rerata tertinggi didapat dari mata pelajaran Bahasa Indonesia dengan angka 64,67 sedangkan mata pelajaran Matematika mendapatkan nilai rerata paling rendah, yakni 45,06. Dimana persentase jawaban siswa yang benar dari materi yang diujikan yaitu bilangan (39,71\%), aljabar (51,24\%), geometri dan pengukuran $(42,27 \%)$ dan statistika peluang $(55,60 \%)$. (Anggraeni, 2019). Sedangkan hasil survei TIMSS yang dilakukan setiap 4 (empat) tahun yang diadakan mulai tahun 1999 tersebut menempatkan Indonesia pada posisi 34 dari 48 negara, tahun 2003 pada posisi 35 dari 46 negara, tahun 2007 pada posisi 36 dari 49 negara, pada tahun 2011 pada posisi 36 dari 40 negara dan pada tahun 2015 Indonesia menempatkan di nomor 45 dari 50 negara dengan skor matematika 397(Danar, 2017). Indonesia masih mengalami kesulitan menghadapi soal matematika terutama soal-soal matematika model TIMSS.

Soal-soal TIMSS tidak hanya menuntut kemampuan dalam penerapan konsep saja, tetapi juga bagaimana konsep tersebut diterapkan, kemampuan siswa dalam berpikir kritis dan berargumentasi mengenai soal yang akan diselesaikan. Hasil penelitian (Mandini, Gity \& Hartono, 2018), mengambil 99 sampel pada siswa SMP Wonosobo dengan melakukan stratifikasi kemampuan pemecahan masalah dengan 3 kategori yakni kategori tinggi, sedang dan kategori rendah. Hasilnya menunjukkan bahwa kemampuan menyelesaikan soal HOTS dan TIMSS berada dalam kategori sedang (85,9\%). Senada dengan hasil penelitian yang lain, (Elfia, 2019), untuk melihat kemampuan pemecahan masalah. Hasil penelitian dari 29 siswa menunjukkan bahwa ada 6 siswa tidak bisa menyelesaikan masalah pada tahap pemahaman masalah. Sebanyak 18 siswa tidak bisa menyelesaikan masalah. Siswa tidak mampu menyimpulkan jawaban sebanyak 23 siswa. 


\section{Histogram: Jurnal Pendidikan Matematika, 4 (2), 2020 - 603 \\ Rahmat Kamaruddin ${ }^{*}$, Firdha Razak ${ }^{2}$, Ahmad Budi Sutrisno ${ }^{3}$}

Penelitian ini menyatakan bahwa kemampuan menyelesaikan masalah siswa pada salah satu SMK di Cimahi masing tergolong rendah sehingga perlu dilakukan peningkatan.

Proses pembelajaran matematika di sekolah menengah belum memberikan pengaruh terhadap pengembangan kemampuan pemecahan masalah siswa. Guru lebih banyak menekankan pada aspek pengetahuan dan pemahaman, sedangkan aplikasi, analisis sintesis dan bahkan evaluasi hanya sebagian kecil dari pembelajaran yang dilakukan sehingga kemampuan pemecahan masalah siswa kurang dapat berkembang dengan baik. Model pembelajaran Creative problem solving (CPS) membangkitkan kemampuan berpikir secara kritis dan kreatif sehingga dapat menyelesaikan masalah yang dihadapi. Rendahnya kemampuan siswa dalam menyelesaikan masalah matematika dikarenakan dalam proses pembelajaran tidak membiasakan siswa untuk berpikir lebih kreatif (Partayasa, I Gusti, 2020). Model CPS tidak hanya terbatas pada tingkat pengenalan, pemahaman dan penerapan sebuah informasi, melainkan juga melatih siswa untuk dapat menganalisis suatu masalah dan memecahkannya. Salah satu media yang cocok digunakan dalam model CPS untuk meningkatkan kemampuan pemecahan masalah siswa adalah Lembar Kerja Siswa (LKS) yang merupakan lembaran yang berisi langkah-langkah penyelesaian yang akan dikerjakan dan didiskusikan secara bersama oleh siswa.

Berdasarkan uraian diatas, rumusan masalah yang akan dikaji dalam penelitian ini adalah: "Bagaimana gambaran kemampuan pemecahan masalah siswa melalui penerapan model pembelajaran creative problem solving berbasis LKS soal TIMSS?". Adapun tujuan penelitian ini adalah menerapkan model pembelajaran creative problem solving berbasis LKS soal TIMSS pada konten aljabar untuk mengukur kemampuan pemecahan pemecahan siswa SMP Negeri 1 Pangkajene.

\section{METODE PENELITIAN}

\section{A. Jenis Penelitian}

Jenis penelitian yang digunakan pada penelitian ini adalah penelitian deskriptif kuantitatif yaitu untuk mendeskripsikan kemampuan pemecahan siswa melalui penerapan model pembelajaran creative problem solving berbasis LKS soal TIMSS.

\section{B. Setting Penelitian}

1. Waktu dan Lokasi Penelitian

Penelitian ini akan dilaksanakan pada tahun ajaran 2020/2021 di kelas VII SMP Negeri 1 Pangkajene Kabupaten Pangkep, tepatnya di Jl. A. Mauraga. 


\section{Histogram: Jurnal Pendidikan Matematika, 4 (2), 2020 - 604 \\ Rahmat Kamaruddin ${ }^{*}$, Firdha Razak ${ }^{2}$, Ahmad Budi Sutrisno ${ }^{3}$}

2. Populasi dan sampel Penelitian

Populasi penelitian ini adalah seluruh siswa kelas VII SMP Negeri 1 Pangkajene berjumlah 180 siswa dan sampel dalam penelitian ini diambil menggunakan tekhnik simple random sampling sebanyak 32 siswa.

\section{Teknik Pengumpulan Data}

Teknik pengumpulan data dalam penelitian ini adalah melalui tes kemampuan pemecahan masalah siswa: (1) Tes berisi soal-soal TIMSS diberikan sebelum penerapan model dan setelah penerapan model untuk melihat sejauhmana daya dongkrak tingkat kemampuan pemecahan masalah siswa melalui model pembelajaran creative problem solving; (2) Pedoman Wawancara digunakan untuk memperoleh data tentang gambaran respon siswa selama penerapan model pembelajaran creative problem solving

\section{Instrumen Penelitian}

Instrumen yang digunakan dalam penelitian ini yaitu (1) Lembar Kegiatan Siswa (LKS) yang berisi soal-soal TIMSS yang mencakup 2 (dua) domain yaitu domain isi dan domain kognitif, (2) Lembar Tes yang berisi soal-soal TIMSS untuk mengukur hasil belajar dan kemampuan pemecahan masalah pada konten Aljabar, (3) Pedoman Wawancara berupa angket yang berisi tentang pernyataan untuk mengetahui respon siswa selama penerapan model pembelajaran creative problem solving.

\section{E. Teknik Analisis Data}

Data akan dianalisis dengan analisis deskriptif kuantitatif serta analisis inferensial.

1. Analisis Deskriptif digunakan untuk mendeskripsikan kemampuan pemecahan masalah oleh siswa dalam bentuk distribusi frekuensi setelah dikonversi ke dalam kriteria seperti pada tabel 1 berikut :

Tabel 1. Kategori Kemampuan Pemecahan Masalah

\begin{tabular}{cc}
\hline Interval & Kategori Penguasaan Siswa \\
\hline $0-54$ & Sangat Rendah \\
$55-64$ & Rendah \\
$65-79$ & Sedang \\
$80-89$ & Tinggi \\
$90-100$ & Sangat Tinggi \\
\hline
\end{tabular}

(Sumber: Azwar, Tahun: 2013)

ISSN: 2549-6700 (print), ISSN 2549-6719 (online) 


\section{Histogram: Jurnal Pendidikan Matematika, 4 (2), 2020 - 605 \\ Rahmat Kamaruddin'1*, Firdha Razak² ${ }^{2}$ Ahmad Budi Sutrisno ${ }^{3}$}

Selanjutnya data yang diperoleh dari hasil pretest dan postest dianalisis dengan menggunakan Uji Gain Ternormalisasi untuk mengetahui sejauh mana peningkatan (daya dongkrak) pemecahan masalah siswa sebelum dan setelah penerapan model pembelajaran creative problem solving. Untuk klasifikasi Gain ternormalisasi dapat dilihat pada tabel 2 berikut :

Tabel 2. Klasifikasi Ngain Ternormalisasi

\begin{tabular}{ll}
\hline \multicolumn{1}{c}{ Nilai Gain (g)Ternormalisasi } & \multicolumn{1}{c}{ Kategori } \\
\hline$-1 \leq \mathrm{g}<0,00$ & Terjadi Penurunan \\
\hline $\mathrm{g}=0.00$ & Tidak Terjadi Penurunan \\
\hline $0,00<\mathrm{g} \leq 0,30$ & Peningkatan rendah \\
\hline $0,30<\mathrm{g}<0,70$ & Peningkatan sedang \\
\hline $0,70 \leq \mathrm{g} \leq 1,00$ & Peningkatan Tinggi
\end{tabular}

(Sumber: Vendiagrys et al., Tahun: 2015)

2. Data respon siswa akan diperoleh dari angket respon siswa yang dibagikan setelah pembelajaran. Kriteria respon siswa akan dianalisis menggunakan tabel distribusi frekuensi kategori respon positif, cenderung positif, cenderung negatif, dan negatif. Penerapan model pembelajaran creative problem solving dinilai berhasil/efektif jika $50 \%$ siswa merespon postive dari $75 \%$ item pernyataan yang diberikan.

3. Analisis statistik inferensial digunakan untuk menguji hipotesis penelitian menggunakan software SPSS. Pengujian hipotesis data posttest dilakukan dengan menggunakan Uji-t dengan analisis One-Sample $\mathrm{T}$ test dengan taraf signifikan yang digunakan adalah 5\% jika memenuhi syarat pengujian, namun jika tidak maka analisis akan dilakukan dengan menggunakan uji Non Parametrik. Adapun Hipotesis yang akan diuji adalah :

a. Ketuntasan Hasil belajar dengan nilai minimal ketuntasan 75

Ho : $\mu \leq 74,9$ melawan H1 : $\mu>74,9$

b. Peningkatan (daya dongkrak) kemampuan pemecahan masalah minimal berada pada kategori sedang dengan nilai $0,30<\mathrm{g}<0,70$.

Ho : $\mu \mathrm{g} \leq 0,30$ melawan $\mathrm{H} 1: \mu \mathrm{g}>0,3$

\section{HASIL DAN PEMBAHASAN}

\section{A. Hasil Penelitian}

Data yang diperoleh dalam penelitian ini adalah : 1) data kemampuan pemecahan masalah siswa yang diperoleh dari tes hasil belajar yang berisi soal-soal TIMSS yang ISSN: 2549-6700 (print), ISSN 2549-6719 (online) 
diberikan sebelum penerapan model dan setelah penerapan model serta melihat daya dongkrak tingkat kemampuan pemecahan masalah siswa melalui model pembelajaran creative problem solving, dan 2) data respon siswa mengenai penerapan model pembelajaran creative problem solving. Data tersebut selanjutnya diolah sesuai dengan langkah - langkah yang telah ditentukan pada teknik analisis data.

1. Kemampuan pemecahan masalah siswa SMP Negeri 1 Pangkajene

Hasil kemampuan pemecahan masalah siswa SMP Negeri 1 Pangkajene yang diperoleh siswa dari tes hasil belajar yang dilakukan selama dua kali yakni sebelum dan sesudah pembelajaran dengan menggunakan soal-soal TIMSS pada konten aljabar. Rangkuman dari hasil analisis data hasil belajar siswa disajikan pada tabel berikut:

Tabel 3. Distribusi Frekunsi Tingkat Kemampuan Siswa Melakukan Penerapan Model Pembelajaran Creative problem solving (CPS)

\begin{tabular}{cccccc}
\hline & Kategori & \multicolumn{2}{c}{ Pre-test } & \multicolumn{2}{c}{ Pos-test } \\
\cline { 3 - 6 } Interval & $\begin{array}{c}\text { Penguasaan } \\
\text { Siswa }\end{array}$ & Frekuensi & $\begin{array}{c}\text { Persentase } \\
\%\end{array}$ & Frekunsi & $\begin{array}{c}\text { Persentase } \\
\%\end{array}$ \\
\hline $0-54$ & Sangat Rendah & 14 & 45 & 0 & 0 \\
$55-64$ & Rendah & 7 & 22 & 0 & 0 \\
$65-79$ & Sedang & 10 & 33 & 12 & 36 \\
$80-89$ & Tinggi & 0 & 0 & 17 & 54 \\
$90-100$ & Sangat Tinggi & 0 & 0 & 3 & 10 \\
\hline & Jumlah & 32 & 100 & 32 & 100
\end{tabular}

(Sumber: Data Primer, Tahun: 2020)

Tabel 3 di atas menunjukkan bahwa kemampuan awal siswa (pretest) terhadap soal-soal TIMSS pada konten aljabar melalui penerapan model pembelajaran Creative problem solving (CPS) ditinjau dari hasil belajar siswa tergolong dalam kategori sangat rendah, rendah dan sedang dimana ada 14 siswa atau $45 \%$ dari mereka yang berada pada kategori sangat rendah memperoleh nilai pada interval $0-54,7$ siswa atau $22 \%$ yang berada pada kategori rendah memperolah nilai pada interval 55-64 dan sisanya yakni sebesar 10 siswa 33\% yang berada pada kategori sedang memperoleh nilai pada interval 65-79, ini berarti bahwa sebelum diajarkan Materi Aljabar, mereka dapat dikatakan cukup memiliki pengetahuan tentang materi tersebut, sedangkan kemampuan akhir siswa (postest) sebanyak 12 siswa atau 36\% berada pada kategori sedang, 17 siswa atau 54\% siswa berada pada kategori tinggi dan 3 siswa atau $10 \%$ berada pada kategori sangat 
Histogram: Jurnal Pendidikan Matematika, 4 (2), 2020 - 607

Rahmat Kamaruddin ${ }^{*}$, Firdha Razak ${ }^{2}$, Ahmad Budi Sutrisno ${ }^{3}$

tinggi. Ini berarti bahwa siswa memperoleh pengetahuan dan mengalami peningkatan hasil belajar tentang materi Aljabar melalui model pembelajaran Creative problem solving (CPS).

Berdasarkan kriteria ketuntasan minimal (KKM) yang berada di SMP Negeri 1 Pangkajene yakni 75, maka tingkat pencapaian ketuntasan hasil belajar matematika siswa secara klasikal pada kelas yang diajar melalui penerapan model pembelajar Creative problem solving (CPS) dapat dilihat pada tabel berikut.

Tabel 4. Distribusi ketuntasan minimal hasil belajar matematika siswa pada kelas berdasarkan penerapan model pembelajaran Creative problem solving (CPS)

\begin{tabular}{|c|c|c|c|}
\hline \multirow[b]{2}{*}{ Hasil Belajar Siswa } & \multirow[b]{2}{*}{ KKM } & \multicolumn{2}{|c|}{ Persentase Ketuntasan Klasikal (\%) } \\
\hline & & Tuntas & Tidak Tuntas \\
\hline pretest & \multirow{2}{*}{75} & 25 & 75 \\
\hline postest & & 94 & 6 \\
\hline
\end{tabular}

(Sumber: Data Primer, Tahun: 2020)

Tabel 4 untuk pretest, ada sebanyak 32 siswa atau $75 \%$ siswa tidak tuntas hasil belajarnya. Jika dikaitkan dengan indikator ketuntasan hasil belajar siswa maka dapat disimpulkan bahwa pretest hasil belajar siswa kelas VII SMP Negeri 1 Pangkajene tidak memenuhi indikator ketuntasan hasil belajar siswa secara klasikal. Sedangkan hasil postest, ada sebanyak 30 siswa atau 94\% siswa yang memenuhi kriteria ketuntasan hasil belajar siswa kelas VII SMP Negeri 1 Pangkajene memenuhi indikator ketuntasan hasil belajar siswa secara klasikal.

Adapun klasifikasi peningkatan hasil belajar siswa yang diajar dengan menerapkan model pembelajaran Creative problem solving (CPS) dihitung dengan gain ternormalisasi. Jika dikatakan hasil belajar matematika siswa dikelompokan ke dalam 3 kategori maka dapat diperoleh distribusi frekunsi dan persentase sebagai berikut : 
Histogram: Jurnal Pendidikan Matematika, 4 (2), 2020 - 608

Rahmat Kamaruddin ${ }^{*}$, Firdha Razak ${ }^{2}$, Ahmad Budi Sutrisno ${ }^{3}$

Tabel 5. Klasifikasi Gain Ternormalisasi Pada Kelas berdasarkan Penerapan Model Pembelajaran Creative problem solving (CPS)

\begin{tabular}{cccc}
\hline $\begin{array}{c}\text { Klasifikasi Normalisasi } \\
\text { Gain }\end{array}$ & $\begin{array}{c}\text { Jumlah } \\
\text { Siswa }\end{array}$ & $\begin{array}{c}\text { Persentase } \\
(\mathbf{\%})\end{array}$ & Klasifikasi \\
\hline$-1 \leq \mathrm{g}<0.00$ & - & - & TerjadiPenurunan \\
$\mathrm{g}=0.00$ & - & - & Tidak terjadi \\
$\mathbf{g} \leq \mathbf{0 , 3}$ & 2 & 6,45 & penurunan \\
$\mathbf{0 , 3}<\mathbf{g}>\mathbf{0 , 7}$ & 27 & 87,10 & Pening. Rendah \\
$\mathbf{g} \geq \mathbf{0 , 7}$ & 3 & 6,45 & Pening. Sedang \\
& & & Pening. Tinggi \\
\hline Rata-rata & & 0,52 & Sedang \\
\hline
\end{tabular}

(Sumber: Data Primer, Tahun: 2020)

Berdasarkan tabel 5 peningkatan hasil belajar siswa yang diajar melalui penerapan model pembelajaran Creative problem solving (CPS) sebagian besar berada pada kategori sedang yaitu sebanyak 27 siswa atau $87,10 \%$ dan 3 siswa atau $6,45 \%$ berada pada kategori tinggi.

Berdasarkan rata-rata pretest dan postest siswa, maka peningkatan hasil belajar siswa yang dihitung dengan rumus gain ternormalisasi sebesar 0,52. Hal ini berarti, peningkatan hasil belajar siswa yang diajar dengan penerapan model pembelajaran Creative problem solving (CPS) berada pada kategori sedang.

2. Respon Siswa

Data respon siswa diperoleh dengan menggunakan angket respon yang diisi oleh siswa. Angket tersebut diberikan setelah penerapan model pembelajaran Creative problem solving (CPS). Hasil analisis data respon siswa terhadap penerapan model pembelajaran Creative problem solving (CPS) yang diisi oleh 32 siswa secara singkat dtunjukkan sebagai berikut:

Tabel 6. Data Hasil Angket Respon Siswa Terhadap Penerapan Model Pembelajaran Creative problem solving (CPS)

\begin{tabular}{|c|c|c|c|c|c|c|}
\hline \multirow[t]{2}{*}{ No } & \multirow[t]{2}{*}{ Pertanyaan } & \multicolumn{4}{|c|}{ Jawaban } & \multirow{2}{*}{$\begin{array}{c}\text { Presentase } \\
\%\end{array}$} \\
\hline & & 4 & 3 & 2 & 1 & \\
\hline 1 & $\begin{array}{l}\text { Saya mudah memahami materi aljabar dengan } \\
\text { penerapan model Creative problem solving (CPS) } \\
\text { karena cara belajarnya berkelompok }\end{array}$ & 9 & 18 & 4 & - & 80 \\
\hline 2 & $\begin{array}{l}\text { Saya dapat memahami dengan jelas cara kerja } \\
\text { diskusi kelompok yang dibimbing guru matematika } \\
\text { dalam pembelajaran dengan model Creative } \\
\text { problem solving (CPS) }\end{array}$ & 13 & 15 & 3 & - & 84 \\
\hline
\end{tabular}


Histogram: Jurnal Pendidikan Matematika, 4 (2), 2020 - 609

Rahmat Kamaruddin ${ }^{*}$, Firdha Razak ${ }^{2}$, Ahmad Budi Sutrisno ${ }^{3}$

\begin{tabular}{|c|c|c|c|c|c|c|}
\hline \multirow{2}{*}{ No } & \multirow{2}{*}{ Pertanyaan } & \multicolumn{4}{|c|}{ Jawaban } & \multirow{2}{*}{$\begin{array}{l}\text { Presentase } \\
\quad \%\end{array}$} \\
\hline & & 4 & 3 & 2 & 1 & \\
\hline 3 & $\begin{array}{l}\text { Saya berminat untuk memecahkan masalah dalam } \\
\text { kehidupan nyata dengan menggunakan model } \\
\text { aljabar yang sudah dipeajari melalui model } \\
\text { pembelajaran Creative problem solving (CPS) }\end{array}$ & 11 & 17 & 3 & - & 80 \\
\hline 4 & $\begin{array}{l}\text { Saya merasa lebih komunikatif dalam dakam belajar } \\
\text { dengan menggunakan model Creative problem } \\
\text { solving (CPS) karena dapat menyalurkan ide } \\
\text { pemecahan masalah dalam kelompok }\end{array}$ & 11 & 15 & 5 & - & 79 \\
\hline 5 & $\begin{array}{l}\text { Kemampuan berpikir dan kreativitas saya lebih } \\
\text { berkembang saat pembelajaran dengan model } \\
\text { Creative problem solving (CPS) }\end{array}$ & 11 & 14 & 6 & - & 79 \\
\hline 6 & $\begin{array}{l}\text { Saya merasa tertarik dengan bimbingan tulisan dan } \\
\text { Langkah-langkah yang terstruktur dalam LKS saat } \\
\text { menyelesaikan permasalahan materi aljabar }\end{array}$ & 10 & 21 & - & - & 84 \\
\hline 7 & $\begin{array}{l}\text { Menurut saya model Creative problem solving } \\
\text { (CPS) membuat kami semakin aktif dan mampu } \\
\text { bekerja sama di dalam pembelajaran Bersama } \\
\text { anggota kelompok yang lain }\end{array}$ & 10 & 15 & 4 & - & 81 \\
\hline 8 & $\begin{array}{l}\text { Saya dapat memahami dengan jelas Bahasa yang } \\
\text { diguanakan dalam LKS }\end{array}$ & 10 & 16 & 4 & - & 80 \\
\hline 9 & $\begin{array}{l}\text { Saya senang jika pembelajaran matematika dengan } \\
\text { model Creative problem solving (CPS) diterapkan di } \\
\text { kelas pada pembelajaran matematika }\end{array}$ & 12 & 15 & 4 & - & 81 \\
\hline 10 & $\begin{array}{l}\text { Bagi saya model pembelajaran Creative problem } \\
\text { solving (CPS) cocok diterapkan untuk materi } \\
\text { matematika yang lainnya }\end{array}$ & 10 & 16 & 5 & - & 79 \\
\hline
\end{tabular}

(Sumber: Data Primer, Tahun: 2020)

Berdasarkan table 6 dari 10 aspek yang direspon, presentase rata-rata siswa yang memberi repon positif terhadap penerapan model Creative problem solving (CPS) sebesar $81 \%$. Karena $81 \%>80 \%$ maka, hal ini menunjukkan bahwa kriteria keefektifan penerapan model pembelajaran Creative problem solving (CPS) untuk respon siswa telah terpenuhi.

\section{Analisis Inferensial}

Analisis Inferensial pada bagian ini dimaksudkan untuk menguji hipotesis penelitian yang berkaitan dengan keefektifan pembelajaran dengan menggunakan model Creative problem solving (CPS)

Uji hipotesis yang dilakukan diawali dengan uji prasyarat yaitu uji normalitas. Setelah pengujian normalitas selanjutnya dialakukan pengujian hipotesis menggunakan 


\section{Histogram: Jurnal Pendidikan Matematika, 4 (2), 2020 - 610 \\ Rahmat Kamaruddin ${ }^{*}$, Firdha Razak ${ }^{2}$, Ahmad Budi Sutrisno ${ }^{3}$}

uji-t yaitu one sample t-test terkait dengan data kemampuan pemecahan masalah pada tes hasil belajar dan peningkatan data kemampuan pemecahan masalah siswa.

a. Uji Normalitas

Pengujian normalitas dilakukan terhadap data kemampuan pemecahan masalah (pre-test dan post-test) dan peningkatan data kemampuan pemecahan masalah siswa yang diajar dengan menggunakan model Creative problem solving (CPS). Pengujian normalitas dengan menggunakan uji statistik uji Kolmogorov-Smirnow yang disajikan sebagai berikut

1) Kemampuan Pemecahan Masalah Siswa

Setelah dilakukan pengolahan data, maka diperoleh tampilan output uji normalitas data kemampuan pemecahan masalah siswa sebelum dan sesudah diterapkan model pembelajaran Creative problem solving (CPS) pada kelas VII SMP Negeri 1 Pangkajene disajikan pada tabel berikut :

Tabel 7. Uji Normalitas Kemampuan Pemecahan Masalah Siswa Kelas VII SMP Negeri 1 Pangkajene

\begin{tabular}{cccc}
\hline & \multicolumn{3}{c}{ Kolmogorov-Smirnow } \\
\cline { 2 - 4 } & Statistik & Df & Sig \\
\hline Pre-test & 0,137 & 32 & 0,146 \\
\hline Post-test & 0,148 & 32 & 0,084 \\
\hline
\end{tabular}

(Sumber: Data Primer, Tahun: 2020 )

Uji normalitas pada tabel 7 menunjukkan bahwa kemampuan pemecahan masalah siswa sebelum diajar dengan model Creative problem solving (CPS) diperoleh nilai sig 0,146 yang lebih besar dari $a=0,5$ untuk uji normalitas Kolmogorov-Smirnow sehingga dapat disimpulakan bahwa data post-test siswa berasal dari data yang berdistribusi normal. Begitupun juga untuk kemampuan pemecahan masalah siswa setelah diajar dengan model pembelajaran Creative problem solving (CPS) diperoleh nilai Sig 0,084 yang lebih lebih besar dari $a=0,05$ sehingga data disimpulkan bahwa data pre-test juga berasal dari data yang berdistribusi normal.

2) Peningkatan Kemampuan Pemecahan Masalah Siswa (NGain)

Setelah dilakukan pengolahan data, tampilan output uji normalitaspeningkatan hasil belajar siswa disajikan pada tabel berikut : 
Histogram: Jurnal Pendidikan Matematika, 4 (2), 2020 - 611

Rahmat Kamaruddin ${ }^{*}$, Firdha Razak ${ }^{2}$, Ahmad Budi Sutrisno ${ }^{3}$

Tabel 8. Normalitas Kemampuan Pemecahan Masalah Siswa Kelas VII SMP Negeri 1 Pangkajene

\begin{tabular}{lccc}
\hline & \multicolumn{3}{c}{ Kolmogorov-Smirnow } \\
\cline { 2 - 4 } & Statistik & Derajat bebas (df) & $\begin{array}{c}\text { Nilai } \\
\text { Signifikansi }\end{array}$ \\
\hline NGain & 0,104 & 32 & 0,200 \\
\hline (Sumber: & Data Primer, Tahun: 2020$)$ &
\end{tabular}

Hasil uji normalistas pada table 6 menunjukkan bahwa peningkatan hasil belajar siswa diperoleh nilai sig 0,200 yang lebih besar dari $a=0,05$ dari uji normalitas Kolmogorov-Smirnow sehingga dapat disimpulkan bahwa data peningkatan kemampuan pemecahan masalah siswa berasal dari data yang berdistribusi normal.

b. Uji Hipotesis

Karena data yang diperoleh berdistribusi normal, maka selanjutnya dapat dilakukan pengujian hipotesis dengan uji-t yaitu one single t-test yaitu dengan mengetahui apakah model pembelajaran Creative problem solving (CPS) efektif diterapkan dalam pembelajaran matematika di SMP Negeri 1 Pangkajene.

1) Ketuntasan Hasil Belajar Matematika Siswa

Pengujian rata-rata hasil belajar siswa pada pada post-test terhadap KKM dilakukan dengan uji one sample t-test menggunakan SPSS 21 for windows. Adapun output haisl pengujian pada table berikut :

Tabel 9. Analisis Inferensial One Sample T-Test Untuk Skor Pada Post-Test Siswa Kelas VII SMP Negeri 1 Pangkajene

\begin{tabular}{|c|c|c|c|c|c|c|}
\hline \multicolumn{7}{|c|}{ Uji t satu sampel } \\
\hline \multicolumn{7}{|c|}{ Nilai $t=75$} \\
\hline & \multirow{2}{*}{$\begin{array}{c}\text { Nilai } \\
\text { tabel } \\
\mathbf{t}\end{array}$} & \multirow{2}{*}{$\begin{array}{l}\text { Derajat } \\
\text { bebas (df) }\end{array}$} & \multirow{2}{*}{$\begin{array}{c}\text { Uji dua } \\
\text { arah }\end{array}$} & \multirow{2}{*}{$\begin{array}{l}\text { Perbedaan } \\
\text { rerata }\end{array}$} & \multicolumn{2}{|c|}{$\begin{array}{c}\text { Taraf kepercayaan } \\
95 \%\end{array}$} \\
\hline & & & & & $\begin{array}{l}\text { Batas } \\
\text { Bawah }\end{array}$ & $\begin{array}{c}\text { Batas } \\
\text { Atas }\end{array}$ \\
\hline $\begin{array}{c}\text { Post- } \\
\text { test }\end{array}$ & 5,218 & 32 & 0,000 & 5,032 & 3,0627 & 7,0018 \\
\hline
\end{tabular}

(Sumber: Data Primer, Tahun: 2020)

Berdasarkan kriteria uji $\mathrm{T}$ sebelumnya, maka tabel 7 menunjukkan bahwa hasil analisis uji one sample $t$-test diperoleh nilai $\mathrm{t}=5,218$ dengan $\mathrm{df}=32$ dan $\mathrm{p}=0,000$ karena nilai $\mathrm{p}<a$ yakni $0,000<0,05$ dengan demikian Ho ditolak. Ini berarti bahwa rata-rata skor hasil belajar matematika siswa setelah diajar dengan menggunakan model pembelajaran Creative problem solving (CPS) lebih besar dari 75 (KKM). 


\section{Histogram: Jurnal Pendidikan Matematika, 4 (2), 2020 - 612 \\ Rahmat Kamaruddin ${ }^{*}$, Firdha Razak ${ }^{2}$, Ahmad Budi Sutrisno ${ }^{3}$}

Hal ini menunjukkan bahwa rata-rata nilai post-test dalam pembelajaran matematika selama 5 pertemuan pada kelas VII SMP Negeri 1 Pangkajene memenuhi kriteria ketuntasan minimal hasil belajar.

2) Peningkatan Hasil Belajar Matematika

Pengujian rata-rata peningkatan kemampuan pemecahan masalah matematika siswa dilakukan dengan uji one sample t-test menggunakan SPSS 21 for windows. Adapun output hasil yang diperoleh hasil pengujian disajikan pada tabel berikut :

Tabel 10. Analisis Inferensial One Sample T-Test Untuk Skor Peningkatan Hasil Belajar Matematika Siswa Kelas VII SMP Negeri 1 Pangkajene

\begin{tabular}{|c|c|c|c|c|c|c|}
\hline \multicolumn{7}{|c|}{ Uji t satu sampel } \\
\hline \multicolumn{7}{|c|}{ Nilai $t=75$} \\
\hline & \multirow{2}{*}{$\begin{array}{c}\text { Nilai } \\
\text { tabel } \\
\mathbf{t}\end{array}$} & \multirow{2}{*}{$\begin{array}{c}\text { Derajat } \\
\text { bebas (df) }\end{array}$} & \multirow{2}{*}{$\begin{array}{l}\text { Uji dua } \\
\text { arah }\end{array}$} & \multirow{2}{*}{$\begin{array}{l}\text { Perbedaan } \\
\text { rerata }\end{array}$} & \multicolumn{2}{|c|}{$\begin{array}{c}\text { Taraf kepercayaan } \\
95 \%\end{array}$} \\
\hline & & & & & $\begin{array}{c}\text { Batas } \\
\text { Bawah }\end{array}$ & $\begin{array}{c}\text { Batas } \\
\text { Atas }\end{array}$ \\
\hline NGain & 7,971 & 30 & 0,000 & 0,215 & 0,160 & ,2707 \\
\hline
\end{tabular}

(Sumber: Data Primer, Tahun: 2020)

Berdasarkan kriteria uji test T pada sebelumnya, maka tabel 8 menggunakan hasil analisis uji one sample t-test di peroleh nilai $\mathrm{t}=7,971$ dengan $\mathrm{df}=30 \mathrm{dan} \mathrm{p}=0,000$ karena nilai $\mathrm{p}<a$ yakni $0,000<0,05$ dengan demikian Ho ditolak . Ini berarti peseta didik setelah diajar dengan menggunakan model pembelajaran Creative problem solving (CPS) memiliki nilai gain lebih besar dari 0,3 . Hal ini menunjukkan bahwa rata-rata peningkatan kemampuan pemecahan masalah matematika siswa dalam pembelajaran matematika selama 5 pertemuan pada kelas VII SMP Negeri 1 Pangkep terdapat peningkatan rata-rata nilai gain ternormalisasi secara signifikan.

Secara inferensial dapat dinyatakan bahwa penerapan model pembelajaran Creative problem solving (CPS) Tuntas secara klasikal serta memiliki daya dongkrak peningkatan gain 0.3 atau terdapat peningkatan rata-rata nilai gain ternormalisasi secara signifikan sehingga model ini baik digunakan dalam pembelajaran matematika di SMP Negeri 1 Pangkajene.

\section{B. Pembahasan}

Pada tahap validasi instrumen penelitian dalam penyusunan LKS serta soal TIMSS melibatkan dua orang validator dari Universitas Negeri Makassar, yaitu Dr. Muhammad Darwis M, M.Pd dan Syahrullah Ashari, S.Pd., M.Pd. Proses Validasi 


\section{Histogram: Jurnal Pendidikan Matematika, 4 (2), 2020 - 613 \\ Rahmat Kamaruddin ${ }^{*}$, Firdha Razak ${ }^{2}$, Ahmad Budi Sutrisno ${ }^{3}$}

dilakukan melalui email dan tatap muka secara langsung. Dr. Muhammad Darwis M, M.Pd sebagai dosen yang aktif dalam penyusunan soal di skala nasional seperti penyusunan buku K13, penyusunan soal SBMPTN, dll diberikan kepercayaan oleh peneliti untuk melakukan validasi isi dan konstruk.

Sedangkan Validator Syahrullah Ashari S.Pd., M.Pd sebagai dosen pada Internasional Class Program melakukan validasi isi dan konstruk bahasa karena beberapa soal LKS dan soal THB dalam penelitian ini diperoleh dari soal berbahasa Inggris yang telah dilombakan pada tahun 1995 - 2003 tingkat Internasional. Berdasarkan hasil uji validasi oleh pakar maka dapat disimpulkan soal-soal model TIMSS yang disusun sudah tergolong baik dan dapat digunakan.

Berdasarkan hasil analisis jawaban siswa saat pretest, terlihat lebih dari setengah atau sekitar $67 \%$ siswa masih berada pada kategori sangat rendah dan rendah, sedangkan 33\% lainnya berada pada kategori sedang, ini berarti bahwa sebalum diajarkan Materi Aljabar, mereka dapat dikatakan cukup memiliki pengetahuan tentang materi tersebut. Pada kemampuan akhir siswa (postest) sebanyak 54\% didominasi oleh siswa yang memiliki kemampuan tinggi, hanya ada 2 orang siswa yang tidak memenuhi ketuntasan individu. Dari hasil jawaban siswa pada pretest dan postest terjadi perkembangan kemampuan pemecahan masalah yang baik. Hal tersebut dapat terlihat dari beberapa indikator-indikator yang terlihat pada jawaban siswa. Indikator-indikator tersebut seperti menganalisis permasalahan secara matematis, memberikan alternatif solusi menggunakan model atau pernyataan matematika, mengintegrasikan fakta dan prosedur untuk mendapatkan solusi akhir yang direncanakan, menyelesaikan permasalahan rutin maupun nonrutin yang mulai terlihat.

Meskipun demikian, masih ada beberapa siswa yang masih kesulitan memberikan penjelasan dengn menggunakan pernyataan matematika serta masih kesulitan dalam membnagun assumsi dalam hal mendukung atau menyaangkal sebuah argumen meskipun pada dasarnya siswa tersebut telah memahami soal yang ada. Selain itu juga terdapat siswa yang tidak dapat mengerjakan soal karena tidak mampu memahami soal dengan baik.

Kebanyakan siswa mengalami kesulitan dalam menyelesaikan soal non rutin, hal tersebut dapat terlihat dari ketidakmampuan siswa dalam menyelesaikan susunan masalah dan kesulitan dalam menerapkan fakta-fakta konsep dan prosedur-prosedur dalam matematika pada konsep yang tidak familiar dan sangat kompleks. Pada soal non rutin ini terlihat siswa hanya mampu mengerjakan soal sampai pada identifikasi masalah. 


\section{Histogram: Jurnal Pendidikan Matematika, 4 (2), 2020 - 614 \\ Rahmat Kamaruddin ${ }^{*}$, Firdha Razak ${ }^{2}$, Ahmad Budi Sutrisno ${ }^{3}$}

Secara keseluruhan, berdasarkan hasil analisis jawaban siswa dapat disimpulkan bahwa siswa dapat memehami dengan baik Soal dan LKS yang telah dikembangkan. Hal tersebut terlihat dari beberapa siswa yang dapat menjawab dengan tepat dan terbangunnya argumentasi matematis siswa yang diuraikan pada lembar jawaban. Selain itu komentar siswa yang diberikan pada angket respon siswa dapat diketahui bahwa secara umum soal pilihan ganda model TIMSS membuat siswa semakin aktif dan semangat kerjasama yang tinggi serta memancing siswa untuk berpikir keras dalam menggunakan penalaran dalam menyelesaikan masalah.

Berdasarkan uraian yang telah dijelaskan sebelumnya maka dapat disimpulkan bahwa penerapan model creative problem solving dapat memberikan stimulus yang baik dalam upaya meningkatkan kemampuan pemecahan masalah, hal tersebut dapat dilihat dari ketuntasan klasikal serta peningkatan nilai gain ternormalisasi yang signifikan khususnya pada Kelas VII SMP Negeri 1 Pangkajene.

\section{KESIMPULAN DAN SARAN}

\section{A. Kesimpulan}

Adapun kesimpulan dari penelitian adalah sebagai berikut : (1) Kemampuan pemecahan masalah siswa(pretest) sesuai aspek yang dinilai dalam TIMSS yang dianalisis secara deskriptif berada pada interpretasi sedang yakni sebesar 10 siswa atau $33 \%$ dari 32 siswa sedangkan kemampuan pemecahan masalah siswa(posttest) berada pada interpretasi tinggi yakni sebesar 17 siswa atau 54\% dari 32 siswa. Sedangkan untuk uji gain ternormalisasi yaitu 0,52 yang berarti peningkatan hasil belajar siswa yang diajar dengan penerapan model pembelajaran Creative problem solving (CPS) berada pada kategori sedang.; (2) Presentase rata-rata siswa yang memberi repon positif terhadap penerapan model Creative problem solving (CPS) sebesar $81 \%$. Karena $81 \%>$ 80\% maka, hal ini menunjukkan bahwa kriteria keefektifan penerapan model pembelajaran Creative problem solving (CPS) untuk respon siswa telah terpenuhi; (3) Secara inferensial, dapat dinyatakan bahwa penerapan model pembelajaran Creative problem solving (CPS) Tuntas secara klasikal serta memiliki daya dongkrak peningkatan gain 0.3 atau terdapat peningkatan rata-rata nilai gain ternormalisasi secara signifikan sehingga model ini baik digunakan dalam pembelajaran matematika di SMP Negeri 1 Pangkajene. 


\section{Histogram: Jurnal Pendidikan Matematika, 4 (2), 2020 - 615 \\ Rahmat Kamaruddin ${ }^{*}$, Firdha Razak ${ }^{2}$, Ahmad Budi Sutrisno ${ }^{3}$}

\section{B. Saran}

Adapun saran dari penelitian adalah sebagai berikut : (1) Disarankan kepada peneliti selanjutnya untuk mempertimbangkan kondisi waktu pada kegiatan penelitian jika terjadi pandemi wabah.; (2) Disarankan kepada peneliti selanjutnya untuk mengembangkan materi penelitian selain materi aljabar yang ada untuk materi-materi yang direkomendasikan oleh TIMSS sehingga diperoleh hasil yang holistic; (3) Kepada pihak sekolah disarankan untuk melatih sejak dini siswa dalam mengerjakan soal berbasis TIMSS.

\section{DAFTAR PUSTAKA}

Anggraeni, P. (2019). ungkap persentase hasil unbk smp 2019. Https://Blog.Ruangguru.Com.

Azwar, S. (2013). Tes Prestasi: Fungsi Pengukuran Prestasi Belajar. Pustaka Belajar. Danar, K. (2017). Peringkat Berapakah Indonesia di TIMSS. Https://Www.Bernas.Id.

Elfia. (2019). Analisis Kemampuan Pemecahan Masalah Matematik Siswa SMK di Kota Cimahi pada Materi Program Linie. Inomatika, l(1).

Mandini, Gity, W., \& Hartono. (2018). Analisis Kemampuan Menyelesaikan soal HOTS Model TIMSS dan Kepercayaan Diri Siswa Sekolah Menengah Pertama. Pytagoras, 13(2).

Partayasa, I Gusti, W. (2020). Pengaruh Model Creative problem solving (CPS) Berbantuan Video Pembelajaran Terhadap Kemampuan Pemecahan Masalah Ditinjau Dari Minat. JNPM, 4(1).

Uno, H. B. (2012). Teori Motivasi dan Pengukurannya Analisis di Bidang Pendidikan. Bumi Aksara.

Vendiagrys, L., Junaedi, I., \& Masrukan. (2015). analisis kemampuan pemecahan masalah matematika soal setipe TIMSS berdasarkan gaya kognitif siswa pada pembelajaran model problem based Learning. Unnes Journal of Mathematics Education Research, 4(1), 34-41. 